\title{
Influence of cold and frozen storage on the chemical content, hydration properties and texture parameters of horse meat
}

\author{
RENATA STANIS ŁAWCZYK, MARIUSZ RUDY, MARIAN GIL, PAULINA DUMA-KOCAN
}

Chair of Agricultural Processing and Commodity Science, Department of Biology and Agriculture, University of Rzeszow, Zelwerowicza Street 4, 35-601 Rzeszow, Poland

Stanisławczyk R., Rudy M., Gil M., Duma-Kocan P.

Influence of horse meat storage in cold and frozen states on its chemical content, hydration properties and texture parameters

\section{Summary}

The aim of the study was to analyse the influence of cold and frozen storage on the chemical content, hydration properties and texture parameters of horse meat. The material were samples of the longest dorsal muscle (m. longissimus dorsi) obtained from thirty six horse half-carcasses from individual farmers in south-eastern Poland. The horses were about 10-years-old and weighed $500-560 \mathrm{~kg}$ before slaughter. One set of samples was subjected to laboratory analyses 24 hours after slaughter. The remaining two sets were subjected to the process of air flow freezing. After freezing, the samples of horse meat were stored for 1 and 3 month periods at a temperature of $-22^{\circ} \mathrm{C}$. The influence of cold and frozen storage on the content of primary chemical composition was not statistically significant in the analysed raw material. Freezing and frozen storage of horse meat contributed significantly to an increase in acidity, darkening of colour and deterioration in hydration properties of the analysed raw material. The study showed a significant decrease in the values of texture parameters of horse meat (chewiness, resilience, hardness and springiness) which was stored in frozen conditions in comparison with the raw material stored in cold conditions.

Keywords: horse meat, texture parameters, hydration properties

Meat belongs to the group of foodstuff with a limited shelf life. Meat spoils easily mainly because of its high content of water which together with proteins and carbohydrates is good food for microorganisms, and of fat, which undergoes processes that accelerate spoilage $(6,11)$. This results in progressive unfavourable changes in the sensory properties, practical usefulness and nutritional value of meat. These quality changes depend mainly on the raw material and the technology used for its processing and preservation (6).

Studies of the physicochemical properties of horse meat have been carried out by many authors $(1,7$, $9,15-17)$. It is distinguished by low levels of fat and cholesterol in comparison with poultry, pork or beef (about 20\% less) (18). High levels of unsaturated fatty acids (above 55\%) and high levels of iron indicate that the consumption of horse meat may be beneficial for human health $(15,18)$. Nowadays, in some European countries (Spain, Belgium, France, Italy) horse meat consumption plays an important role (9).

The extended storage time of raw materials and meat products in cold and frozen conditions is achieved by slowing down the microbiological, chemical and biochemical processes of decomposition. Freezing is one of the most effective methods of meat preservation (8, 25 ). The freezing of meat results in intensive processes related to water freezing and forming ice crystals inside muscle structures $(3,10,19)$. A negative result of the crystallization of cell juice in meat during freezing is the disturbance of cell and colloidal structures, with a simultaneous deterioration in physicochemical properties of muscle proteins, especially myofibrillar, through partial denaturation. This is accompanied by an increase in the volume of ice, an increase in the ionic strength of that solution, and a change in surface tension and environment $\mathrm{pH}$. Among other things, there is a deterioration in functional meat properties, such as the solubility of meat proteins, water absorption, fat emulsification and the thermal stability of the resultant emulsions $(4,13,23,35)$.

Given the above facts, the present study was carried out to analyse the influence of cold and frozen storage of horse meat on the chemical content, hydration properties and texture parameters of horse meat. 


\section{Material and methods}

Raw material. The material were samples of the longissimus dorsi muscle obtained from thirty six horse half carcasses from individual farmers in south-eastern Poland. The horses were about 10-years-old and weighted 500$-560 \mathrm{~kg}$ before slaughter. In order to determine the chemical content, hydration properties and texture of meat, three samples of $700 \mathrm{~g}$ were taken from the longest dorsal muscle at the height of the $12-14^{\text {th }}$ thoracic vertebra. Next, the samples were cleaned from external fat, connective tissue and sinews. One set of samples, intended for laboratory analyses, was kept in cool conditions $\left(6^{\circ} \mathrm{C}\right)$. The analyses of cooled meat were carried out 24 hours after slaughter. The remaining two sets of meat samples were subjected to the process of air flow freezing. The freezing of samples was carried out in a freezing cabinet of a Budget Line type, after vacuum-packing them in PA/PE bags. The average temperature of samples before freezing was $4^{\circ} \mathrm{C}$. The time of freezing the meat at $-28^{\circ} \mathrm{C}$ was approx. 3 hours. After freezing the meat samples were stored for 1 and 3 month periods at a temperature of $-22^{\circ} \mathrm{C}$. After the predetermined period of storage the samples were moved to the laboratory for analyses. Sample quality testing was performed after the packed samples had been thawed in air at a temperature of approx. $10^{\circ} \mathrm{C}$. Defrosting was stopped after the temperature inside the meat had reached $0^{\circ} \mathrm{C}$.

Analyses of cooled meat were carried out 24 hours after slaughter. In the case of meat stored under freezing conditions, analyses were carried out immediately after thawing.

Analytical methods. The following analyses of meat were carried out: active acidity $(\mathrm{pH})$, colour, primary chemical content (content of water, protein and fat), hydration properties (water holding capacity, thermal drip and thawing drip), parameters of texture (hardness, springiness, chewiness, resilience and cohesiveness).

Active acidity of cooled meat was analysed with an $\mathrm{OSH}$ 12-01 electrode and a CPC-411 pH meter (ELMETRON) with a measuring accuracy of $0.01,24$ hours after slaughter. In the case of meat stored under freezing conditions, analyses were carried out immediately after thawing.

Meat colour was assessed visually according to the standards of the Italian company "Soicarnia" on a scale from 4 to 8 ( 4 points - light pink meat, 8 points - dark red or brown meat). The assessment of colour was made on a slice of meat (1.5-2.0 cm thick) within 10 minutes after it had been cut off the sample, in daylight and in a place not exposed to direct sunlight.

Water content was determined in accordance with PN-ISO 1442:2000 standard (27).

Protein was determined with the Kjeldahl method, where the determined value of nitrogen was recalculated to protein according to PN-75/A-04018 Polish standard (26).

Fat content was determined with the Soxhlet method, as per recommendations in PN-ISO 1444:2000 Polish standard (28).

Thawing drip was determined after the thawing of meat samples. Drip weight of plasma was determined in comparison with sample weight (with a precision of $0.01 \mathrm{~g}$ ). The value of that feature was expressed as a drip percentage:

$$
\mathrm{T}_{\mathrm{d}}(\%)=\left(\frac{\mathrm{M}_{\mathrm{I}}-\mathrm{M}_{\mathrm{II}}}{\mathrm{M}_{\mathrm{I}}}\right) 100 \%
$$

where: $T_{d}$ - the size of thawing drip (\%), $M_{I}$ - weight of sample before thawing $(\mathrm{g}), \mathrm{M}_{\mathrm{II}}$ - weight of sample after thawing $(\mathrm{g})$.

In order to carry out consecutive analyses of physicochemical characteristics, i.e. thermal drip and water holding capacity, meat samples were minced twice in a laboratory grinder with the use of sieves with meshes of $4.0 \mathrm{~mm}$. The obtained mince was thoroughly mixed in order to homogenize the sample.

The size of thermal drip (meat samples were brewed at a temperature of $85^{\circ} \mathrm{C}$ for 10 minutes) was calculated from the difference between the weight before the thermal processing and the weight after cooling according to the formula:

$$
\mathrm{T}_{\mathrm{d}}(\%)=\left(\frac{\mathrm{M}_{\mathrm{I}}-\mathrm{M}_{\mathrm{II}}}{\mathrm{M}_{\mathrm{I}}}\right) 100 \%
$$

where: $\mathrm{T}_{d}-$ the size of thermal drip (\%), $\mathrm{M}_{\mathrm{I}}$ - weight of sample before thermal processing $(\mathrm{g}), \mathrm{M}_{\mathrm{II}}$ - weight of sample after cooling $(\mathrm{g})$.

Water holding capacity (forced drip) was determined according to the Grau and Hamm method (22). The minced sample (approx. $300 \mathrm{mg}$ ) was placed on filter paper (Whatman No 1). The filter paper with the sample was put between two glass plates and subjected to constant pressure of $5 \mathrm{~kg}$ for the period of 5 minutes. After the predetermined time of pressure the surface occupied by the meat sample was outlined, as was the surface occupied by drip of meat juice. Next the surfaces were planimetered. The difference between two surfaces was the measure of forced drip of meat juice which was calculated as $0.3 \mathrm{~g}$. The result expressed water absorption $\left(\mathrm{cm}^{2}\right)$ (higher value - lower water absorption of meat).

In order to determine the texture parameters of the analysed meat, from each set of meat samples were cut out in the shape of cubes with sides of $30 \mathrm{~mm}$. The texture parameters of the analysed samples were determined instrumentally employing texture profile analysis (TPA) with the use of texturometer Texture Analyser - CT3 - 25 of the Brookfield company with a roll-shaped attachment which was $50.8 \mathrm{~mm}$ in diameter and $20 \mathrm{~mm}$ in length. A test of compression of samples to $50 \%$ of their height was performed twice. The speed of roll travel during the test was $2 \mathrm{~mm} / \mathrm{sec}$ and the interval between compressions was 2 seconds. The following texture parameters: hardness $(\mathrm{N})$, springiness $(\mathrm{mm})$, chewiness $(\mathrm{mJ})$, resilience and cohesiveness were determined through Texture Pro CT program. During serial measurements the texture parameters were calculated automatically.

Statistical analysis. The obtained results were grouped and subjected to statistical calculations. The mean $(\overline{\mathrm{x}})$ for each analysed characteristic and values of standard deviation (s) were presented. In calculation univariate analysis of variance was employed and the significance of differences between averages $(p \leq 0.05)$ was determined through RIR Tukey's test. All statistical calculations were made in STATICA v. 10 program. 


\section{Results and discussion}

Horse meat belongs to animal raw materials which are characterized by low fat content $(2.9 \%)$ and high protein content $(22.5 \%)$ (34). Similar observations were made by Diaconu et al. (5), Lorenzo and Pateiro (16), Palo P. De et al. (24), Franco et al. (7), Lorenzo et al. (17), Lorenzo et al. (18), Lorenzo and Carballo (15). Numerical values, obtained in the studies, concerning chemical content of horse meat were presented in Tab. 1 .

The data show that average water content in analysed muscles was $73.67 \%$, protein $20.19 \%$ and fat $4.47 \%$. Further analysis of the data indicates that the storage of horse meat in cold and frozen conditions did not have a statistically significant influence on the content of the primary elements in the analysed raw material. This is evidently because it is difficult to expect quantity changes in tightly packed meat under frozen storage. Structural changes of frozen raw material usually cause unfavourable derivative changes; among other things, limitation of water holding capacity and higher thawing drip. That fact is also confirmed by the increasing size of the thawing drip in the authors' own studies (Tab. 2). With the extension of the time of frozen storage from 1 to 3 months, an increase in the size of the thawing drip by $0.65 \%$ was observed, although that dependence was not confirmed statistically. An increase in the size of thawing drip with extension of frozen storage of horse meat was shown in other studies $(32,31)$. Muela et al. (20) observed similar regularities studying the thawing drip of meat of different animal species.

Among many post-slaughter factors which decide about meat quality, $\mathrm{pH}$ value is essentially important. Meat acidity determines the degree of advancement of the maturing process of the raw material, influences its colour, water absorption, tenderness, taste and shelf

Tab. 1. Chemical composition of horse meat $(\% ; \overline{\mathbf{x}} \pm \mathbf{s})$

\begin{tabular}{|l|r|r|r|r|r|r|}
\hline \multirow{2}{*}{ Component } & \multicolumn{2}{|c|}{$\begin{array}{c}\text { Meat stored in cold } \\
\text { conditions }\end{array}$} & \multicolumn{3}{|c|}{$\begin{array}{c}\text { Meat stored in frozen conditions } \\
\text { one month }\end{array}$} & \multicolumn{2}{|c|}{ three months } \\
\hline Fat & $4.47^{\mathrm{a}}$ & 0.90 & $4.95^{\mathrm{a}}$ & 1.00 & $5.22^{\mathrm{a}}$ & 1.68 \\
Protein & $20.19^{\mathrm{a}}$ & 0.23 & $20.25^{\mathrm{a}}$ & 0.23 & $20.14^{\mathrm{a}}$ & 0.70 \\
Water & $73.67^{\mathrm{a}}$ & 1.09 & $73.38^{\mathrm{a}}$ & 0.99 & $72.85^{\mathrm{a}}$ & 1.34 \\
\hline
\end{tabular}

Explanation: a - means in the row with superscript the same letters do not differ significantly

Tab. 2. Hydration properties, colour and $\mathrm{pH}$ of horse meat $(\overline{\mathrm{x}} \pm \mathbf{s})$

\begin{tabular}{|l|l|c|c|c|c|c|c|}
\hline \multicolumn{1}{|c|}{ Properties of meat } & \multirow{2}{*}{ Unit } & \multicolumn{2}{c|}{$\begin{array}{c}\text { Meat stored in cold } \\
\text { conditions }\end{array}$} & \multicolumn{3}{c|}{ Meat stored in frozen conditions } \\
one month & \multicolumn{2}{c|}{ three months } \\
\hline pH & & $5.80^{\mathrm{a}}$ & 0.16 & $5.57^{\mathrm{b}}$ & 0.08 & $5.58^{\mathrm{b}}$ & 0.13 \\
\hline Meat colour & $\mathrm{score}$ & $6.20^{\mathrm{a}}$ & 0.89 & $6.83^{\mathrm{ab}}$ & 0.80 & $7.41^{\mathrm{b}}$ & 0.41 \\
\hline Thermal drip & $\%$ & $26.58^{\mathrm{a}}$ & 1.96 & $27.18^{\mathrm{a}}$ & 1.26 & $27.25^{\mathrm{a}}$ & 1.04 \\
\hline Water holding capacity (forced drip) & $\mathrm{cm}^{2}$ & $4.11^{\mathrm{a}}$ & 0.47 & $4.26^{\mathrm{a}}$ & 1.08 & $7.15^{\mathrm{b}}$ & 1.04 \\
\hline Thawing drip & $\%$ & - & - & $8.33^{\mathrm{a}}$ & 2.03 & $8.98^{\mathrm{a}}$ & 1.66 \\
\hline
\end{tabular}

Explanation: ${ }^{\mathrm{a}, \mathrm{b}}$ - means with different superscript letters differ significantly in the row at $\mathrm{p} \leq 0.05$ life, i.e. it decides about the technological and culinary usefulness of meat. Kwiastowska's studies (12) show that the process of glycolysis in horse meat usually is fastest on the $1^{\text {st }}$ day after slaughter, where the initial content of glycogen decreased by $46.2 \%$. 3 days after slaughter that raw material obtains the lowest $\mathrm{pH}$ content. In the authors' own studies, 24 hours after slaughter $\mathrm{pH}$ value was at the level of 5.80. Moreover, Seong et al. (30), analysing acidity of horse meat stored in cold conditions through 24 hours, indicated $\mathrm{pH}$ at the level of 5.80. Results presented in table 2 indicate that the acidity of horse meat, in fact, depends on the length of time of cold and frozen storage. The process of freezing and frozen storage caused a significant increase in acidity of horse meat in comparison with raw material stored in cold conditions. In the case of raw material stored under frozen conditions for one and three months the acidity of horse meat was at a similar level and $\mathrm{pH}$ value was 5.57 and 5.58 respectively. Other research studies inform about an increase in acidity of horse meat in frozen storage in comparison with cold storage (32).

An important criterion for the customer deciding to buy meat is its colour. Meat dye responsible for the impression of colour is myoglobin which by the oxygenation becomes oxymyoglobin, and then by oxidation can become metmyoglobin $(24,30)$. According to many authors $(18,30)$ horse meat is characterized by a high content of myoglobin. In the authors' own research the statistical analysis showed that significant differences in the colour of analysed raw material depend on storage conditions. The freezing process and frozen storage to three months resulted in the colour of horse meat substantially darkening in comparison with raw material stored in cold conditions. Stanisławczyk and Rudy (32) observed similar regularities in their research analysing horse meat, while Domaradzki et al. (6) and Litwińczuk et al. (14) observed similar regularities in their research analysing beef.

Table 2 presents data concerning changes of hydration properties of horse meat depending on cold time and frozen storage. The data show that horse meat stored in cold conditions 24 hours after slaughter was characterized by the lowest thermal drip (26.58\%) and forced drip $\left(4.11 \mathrm{~cm}^{2}\right)$. Immediately after slaughter the meat with a high content of ATP and glycogen shows the highest water holding capacity, which is connected with a high level of $\mathrm{pH}$ of muscle tissue. In authors' own research the freezing process and frozen storage had a negative influence on the specified hydra- 
tion properties of horse meat and caused a decrease in water bonding and holding capacity. With an extension of frozen storage time the statistical analysis showed significant differences in the size of forced drip. After 3 months of frozen storage the value of this characteristic increased to the level of $7.15 \mathrm{~cm}^{2}$. Considering the size of thermal drip, there were not statistically significant differences in the size of that quality indicator of meat that would depend on

Tab. 3. Texture parameter of horse meat $(\bar{x} \pm s)$

\begin{tabular}{|c|c|c|c|c|c|c|c|}
\hline \multirow{3}{*}{$\begin{array}{c}\begin{array}{c}\text { Properties } \\
\text { of meat }\end{array} \\
\text { Hardness }\end{array}$} & \multirow{3}{*}{$\begin{array}{l}\text { Unit } \\
\mathbf{N}\end{array}$} & \multirow{2}{*}{\multicolumn{2}{|c|}{$\begin{array}{l}\text { Meat stored in cold } \\
\text { conditions }\end{array}$}} & \multicolumn{4}{|c|}{ Meat stored in frozen conditions } \\
\hline & & & & \multicolumn{2}{|c|}{ one month } & \multicolumn{2}{|c|}{ three months } \\
\hline & & $36.10^{\mathrm{a}}$ & 16.69 & $21.47^{b}$ & 8.50 & $25.49^{a b}$ & 13.02 \\
\hline Springiness & $\mathrm{mm}$ & $8.10^{\mathrm{a}}$ & 2.86 & $6.42^{\mathrm{ab}}$ & 1.96 & $5.12^{\mathrm{b}}$ & 0.98 \\
\hline Gumminess & $\mathbf{N}$ & $10.07^{a}$ & 4.14 & $5.94^{\mathrm{b}}$ & 2.72 & $5.44^{\mathrm{b}}$ & 3.44 \\
\hline Chewiness & mJ & $83.27^{\mathrm{a}}$ & 46.19 & $42.12^{b}$ & 28.74 & $29.66^{b}$ & 22.73 \\
\hline Resilience & - & $0.15^{a}$ & 0.04 & $0.11^{b}$ & 0.02 & $0.09^{\mathrm{b}}$ & 0.01 \\
\hline Cohesiveness & - & $0.30^{\mathrm{a}}$ & 0.15 & $0.28^{\mathrm{a}}$ & 0.12 & $0.20^{\mathrm{a}}$ & 0.02 \\
\hline
\end{tabular}

Explanation: as in Tab. 2 the time of cold and frozen storage. However, a tendency was observed towards an increase in the size of thermal drips with the extension of the time of frozen storage of horse meat. Determining the amount of thermal drip is very important because it informs us about the loss of muscle juice, which may result from thermal processing of meat (29). While analysing meat of different species of animals Stanisławczyk and Rudy (32), Stanisławczyk and Znamirowska (33) and Chwastowska and Kondratowicz (3) obtained similar results, i.e. the deterioration in hydration features of horse meat as a result of the freezing process and frozen storage. In Lorenzo et al. (17), the amount of defects resulting from thermal treatment (grilling) in various horse muscles ranged from 17.20 to $20.34 \%$, while Franco et al. (7) did not show a statistically significant influence of gender and age of animals on the value of this feature.

Texture is a principal quality parameter and it decides about the values of sensory features of red meat (6). It is a complex of physical features resulting from the structure and cohesion of particles (21). Information included in literature indicates that the structure of horse meat is cohesive and compact. Its consistency is relatively hard. Raw material obtained from old horses is usually characterized by undesirable fibrousnesses and hardness. One of the causes of the above disadvantage of this type of meat is a larger participation of connective tissue (collagen) in comparison with others types of that raw material $(1,32)$.

Table 3 presents texture parameters of horse muscle under cold and frozen storage. The data show that values of all texture parameters of horse meat stored in cold conditions 24 hours after slaughter were higher in comparison with meat samples subjected to a freezing process and frozen storage.

Meat hardness is a strength necessary to obtain its specified deformation or deep penetration. it is shaped mainly by myofibrillar proteins, especially in the state of their countermove and the quantity and quality of connective tissue (collagen hardness). The data presented in table 3 show that raw material stored for 24 hours in cold storage is characterized by the highest hardness $(36.10 \mathrm{~N})$. The freezing process and frozen storage up to one month significantly contributed to a decrease in horse meat hardness by $14.63 \mathrm{~N}$.

Lorenzo et al. (17) obtained a hardness value of $4.11 \mathrm{~kg}$ in LD (longissimus dorsi) to $6.34 \mathrm{~kg}$ in SM (semimembranous), while Franco et al. (7) obtained the value of 3.03 and $2.53 \mathrm{~kg} / \mathrm{cm}^{2}$ for male and female subjects respectively.

Springiness - in other words, flexibility presented in $\mathrm{mm}$ - is a speed of return of an analysed sample from a deformed state to the initial one (2). In the authors' own studies the samples of horse meat stored for 24 hours in cold conditions were characterized by the highest resilience at the level of $8.10 \mathrm{~mm}$. A statistically significant decrease in horse meat resilience to the level of $5.12 \mathrm{~mm}$ was observed in the case of meat samples stored in frozen conditions through 3 months.

Chewiness is a necessary work needed to destroy internal bonds of an analysed sample - in this case horse meat sample. It is a secondary parameter that depends on hardness, cohesiveness and springiness. The authors' own research showed that texture parameters of horse meat, such as chewiness and resilience, undergo significant changes due to the freezing process and in the time of one month of frozen storage. The values of those parameters were respectively about $49.41 \%$ and $26.66 \%$ lower in comparison with values after 24 hours of storage in cold conditions. As the time of frozen storage was extended to 3 months the analysed texture parameters indeed underwent a further decrease by $64.38 \%$ and $40 \%$. Moreover, the authors' own studies showed a lower cohesion value, although not statistically confirmed, of horse meat which underwent the freezing process and frozen storage. Horse meat stored in cold conditions 24 hours after slaughter was characterized by the highest cohesion at the level of 0.30. Lorenzo et al. (16) in the study of selected horse muscles showed the values of cohesion within 0.53 (LD) to 0.57 (SM and TB).

The content of basic chemical components in horse meat does not change in the analyzed period of cold ( 24 hours) and frozen storage ( 1 and 3 months). Horse meat kept in cold storage for 24 hours after slaughter is a better raw material for processing (more favourable hydration properties) in comparison with meat kept in frozen storage for 1 and 3 months. Horse meat kept in frozen storage is a better raw material for culinary purposes due to its more favourable tenderness in comparison with horse meat kept in cold storage. 


\section{References}

1. Arcos-Garcia G., Totosaus A., Guerrero I., Perez-Chabela M. L.: Physicochemical, sensory, functional and microbial characterization of horse meat. Rev. Bras. Agrociência 2002, 8, 43-46.

2. Chang H. J., Wang Q., Zhou G. H., Xu X. L., Li C. B.: Influence of weak organic acids and sodium chloride marination on characteristics of connective tissue collagen and textural properties of beef semitendinosus muscle. J. Texture Stud. 2010, 41, 279-301.

3. Chwastowska I., Kondratowicz J.: Właściwości technologiczne mięsa wieprzowego w zależności od czasu zamrażalniczego przechowywania i metody rozmrażania. Żywn. Nauka Techn. Jakość 2005, 3, 11-20.

4. Chwastowska I., Kondratowicz J.: Wpływ warunków zamrażalniczego przechowywania i technologii rozmrażania na jakość mięsa. Chłodnictwo 2007, $4,40-44$.

5. Diaconu E. C., Lazăr R., Găină (Diaconu) N., Ciobanu M. M., Boișteanu P. C.: Research regarding nutritional characterization of horse meat. Scientific Papers-Animal Science Series: Lucrări Ştiinţifice - Seria Zootehnie 2015, 63, 40-43.

6. Domaradzki P., Skałecki P., Florek M., LitwińczukA.: Wpływ przechowywania zamrażalniczego na właściwości fizykochemiczne mięsa wołowego pakowanego próżniowo. Żywn. Nauka Techn. Jakość 2011, 4, 117-126.

7. Franco D., Rodríguez E., Purriňos L., Crecente S., Bermúdez R., Lorenzo J. M.: Meat quality of "Galician Mountain" foals breed. Effect of sex, slaughter age and livestock production system. Meat Sci. 2011, 88, 292-298.

8. Jo Y. J., Jang M. Y., Jung Y. K., Kim J. H., Sim J. B., Chun J. Y., Yoo S. M., Han G. J., Min $S$. G.: Effect of novel quick freezing techniques combined with different thawing processes on beef quality. Korean J. Food Sci. Anim. Resour. 2014, 34, 777-783.

9. Juárez M., Polvillo O., Gómez M. D., Alcalde M. J., Romero F., Valera M.: Breed effect on carcass and meat quality of foals slaughtered at 24 months of age. Meat Sci. 2009, 83, 224-228.

10. Kiani H., Sun D. W.: Water crystallization and its importance to freezing of foods: A review. Trends Food Sci. Tech. 2011, 22, 407-426.

11. Kumar Y., Yadav D. N., Ahmad T., Narsaiah K.: Recent trends in the use of natural antioxidants for meat and meat products. Compr. Rev. Food Sci. F. 2015, 14, 796-812.

12. Kwiatkowska A. M.: Glikoliza w mięśniach szkieletowych tusz koni w zależności od temperatury poubojowego przechowywania i jej wpływ na cechy jakościowe mięsa. Wydawnictwo Uniwersytetu Warmińsko-Mazurskiego, Olsztyn 2002

13. Leygonie C., Britz T. J., Hoffman L. C.: Impact of freezing and thawing on the quality of meat: Review. Meat Sci. 2012, 91, 93-98.

14. Litwińczuk Z., Florek M., Ryszkowska-Siwko M.: Changes in beef meat colour and tenderness after different cold storage and freezing periods. Ann. Anim. Sci. 2005, 2, 91-94.

15.Lorenzo J. M., Carballo J.: Changes in physico-chemical properties and volatile compounds throughout the manufacturing process of dry-cured foal loin. Meat Sci. 2015, 99, 44-51.

16. Lorenzo J. M., Pateiro M.: Influence of type of muscles on nutritional value of foal meat. Meat Sci. 2013, 93, 630-638.

17. Lorenzo J. M., Pateiro M., Franco D.: Influence of muscle type on physicochemical and sensory properties of foal meat. Meat Sci. 2013, 94, 77-83.

18. Lorenzo J. M., Sarries M. V., Tateo A., Polidori P., Franco D., Lanza M.: Carcass characteristics, meat quality and nutritional value of horsemeat: A review. Meat Sci. 2014, 96, 1478-1488.

19. Marchel J., Żmijewski T., Cierach M., Malczyk E.: Wpływ przechowywania mięsa wołowego w stanie zamrożonym na wielkość wycieków rozmrażalniczych i cieplnych oraz teksturę mięsa. Acta Agrophys. 2013, 20, 377-387.

20. Muela E., Sañudo C., Campo M. M., Medel I., Beltrán J. A.: Effect of freezing method and frozen storage duration on instrumental quality of lamb throughout display. Meat Sci. 2010, 84, 662-669

21. Niedźwiedź J., Ostoja H., Cierach M.: Instrumentalny pomiar parametrów tekstury i ocena organoleptyczna kruchości wołowego mięsa kulinarnego. Inż. Ap. Chem. 2013, 52, 2, 62-64.

22. Oeckel M. J. Van., Warnants N., Boucqueé Ch. V.: Comparison of different methods for measuring water holding capacity and juiciness of pork versus online screening methods. Meat Sci. 1999, 51, 313-320.

23. Oliveira M. R., Gubert G., Roman S. S., Kempka A. P., Prestes R. C.: Meat quality of chicken breast subjected to different thawing methods. Braz. J. Poultry Sci. 2015, 17, 2, 165-172.

24. Palo P. De, Maggiolino A., Centoducati P., Tateo A.: Colour changes in meat of foals as affected by slaughtering age and post-thawing time. Asian-Aust. J. Anim. Sci. 2012, 25, 1775-1779.

25. Pham Q. T: Advances in food freezing/thawing/freeze concentration modelling and techniques. Japan J. Food Engin. 2008, 9, 1, 21-32.
26. PN-75/A-04018. Agricultural food products. Determination of nitrogen by the Kjeldahl method and expressing as protein.

27. PN-ISO 1442:2000. Meat and meat products - Determination of moisture content (Reference method).

28. PN-ISO 1444:2000. Meat and meat products - Determination of free fat content.

29. Rudy M., Roch A., Stanisławczyk R., Duma P.: Wpływ rasy bydła na wybrane cechy jakościowe cielęciny przechowywanej w warunkach chłodniczych. Rocz. Nauk. Pol. Tow. Zootech. 2014, 10, 45-53.

30. Seong P. N., Park K. M., Kang G. H., Cho S. H., Park B. Y., Chae H. S., Ba $H$. $V$ : The differences in chemical composition, physical quality traits and nutritional values of horse meat as affected by various retail cut types. AsianAust. J. Anim. Sci. 2016, 29, 89-99.

31. Stanisławczyk R.: Wpływ wieku koni na zmiany właściwości hydratacyjnych mięsa końskiego w czasie chłodniczego i zamrażalniczego przechowywania. Chłodnictwo 2011, XLVI, 7, 34-37.

32. Stanisławczyk R., Rudy M.: Zmiany właściwości fizyko-chemicznych mięsa chłodzonego i mrożonego w zależności od wieku koni. Chłodnictwo 2010, XLV, 12, 36-39.

33. Stanistawczyk R., Znamirowska A.: Changes in physico-chemical properties of horsemeat during frozen storage. Acta Sci. Pol. Technol. Aliment. 2005, 4, 89-96.

34. Tonial I. B., Aguiar A. C., Oliveira C. C., Bonnafé E. G., Visentainer J. V.: Fatty acid and cholesterol content, chemical composition and sensory evaluation of horsemeat. S. Afr. J. Anim. Sci. 2009, 39, 328-332.

35. Zymon M., Strzetelski J., Pustkowiak H., Sosin E.: Effect of freezing and frozen storage on fatty acid profile of calves' meat. Pol. J. Food Nutr. Sci. 2007, 57, 647-650.

Corresponding author: Renata Stanisławczyk, Eng. PhD, ul. Zelwerowicza 4, 35-601 Rzeszów, Poland; e-mail: rstanisl@univ.rzeszow.pl 